\title{
Protein in the Diet of the Isoko Tribe of the Niger Delta
}

\author{
By B. M. Nrcol, Colonial Medical Service, Nigeria
}

The British Colony and Protectorate of Nigeria is only a small part of the continent of Africa, but covers an area four times that of the United Kingdom and has a native population of about 40 millions. The non-native population, mostly British, amounts to about 12,000 . From the arid sahel savannah on the northern frontier the rainfall and vegetation increase as one moves southwards, through sudan and guinea savannah, high forest, tropical rain forest and freshwater swamp to the mangrove-fringed creeks which flow into the Gulf of Guinea.

\section{The Isoko tribe}

The Isoko are a small tribe not more than a few thousand strong, typical of the peasants who farm in the rain forest and on the banks of the streams which form the freshwater swamps during the wet season. Their staple crops are yam (Dioscorea) and cassava (Manihot utilissima), but they also cultivate cocoyam (Colocasia) and plantains (Musa paradisiaca). They catch fish during the rainy season, and trade their root crops to the Ijaw fishermen who live on the sea coast and in the mangrove swamps about 30 miles to the south. They sell or barter palm oil and palm kernels at the small outposts of the trading firms. Pigs, goats and sheep are to be found in small numbers in the villages, but these animals are not tended, and are only slaughtered on some special village occasion such as a wedding or funeral. Chickens are reared for sacrifice to one or other of the innumerable local 'juju' or for sale to Europeans. Muturu cattle, which thrive in these districts, roam unherded through the bush, but are the property of the local chief, are only killed on his instructions and thus are not available to the population as a whole.

The main enemies of the Isoko are subtertian malaria, leprosy and helminthic infestations, crocodiles and bush-cow. With the advent of British administration, education and a limited medical and health service, they have been protected from tribal wars and a proportion of the sickness from which they used to suffer, and firearms afford some protection from the larger animals. As a result the population is increasing, but food supplies are not keeping pace with this increase, since the literate and semi-literate tend to drift into the towns and unproductive employment. Under such circumstances the Isoko continue an existence which is never easy and frequently hazardous.

\section{The diet of the Isoko}

The diet of the Isoko was studied in 1949 and $195^{\circ}$, and during I year all food prepared for cooking in three compounds was weighed and measured for four periods of a week each. The details of this investigation have been published elsewhere (Nicol, I952). In this paper only the protein content of the diet, its sources and the methods used to procure animal foodstuffs will be discussed. 
Table I summarizes the mean daily food intake of the adult members of the population. In the absence of analytical data for certain of the animal foods consumed, the protein content has been estimated by analogy. The figures presented in Table I illustrate certain points which are considered to be of interest and importance.

Table $\mathrm{x}$. The average daily food consumption of Isoko adults, showing the amounts of protein provided by vegetable and animal foodstuffs

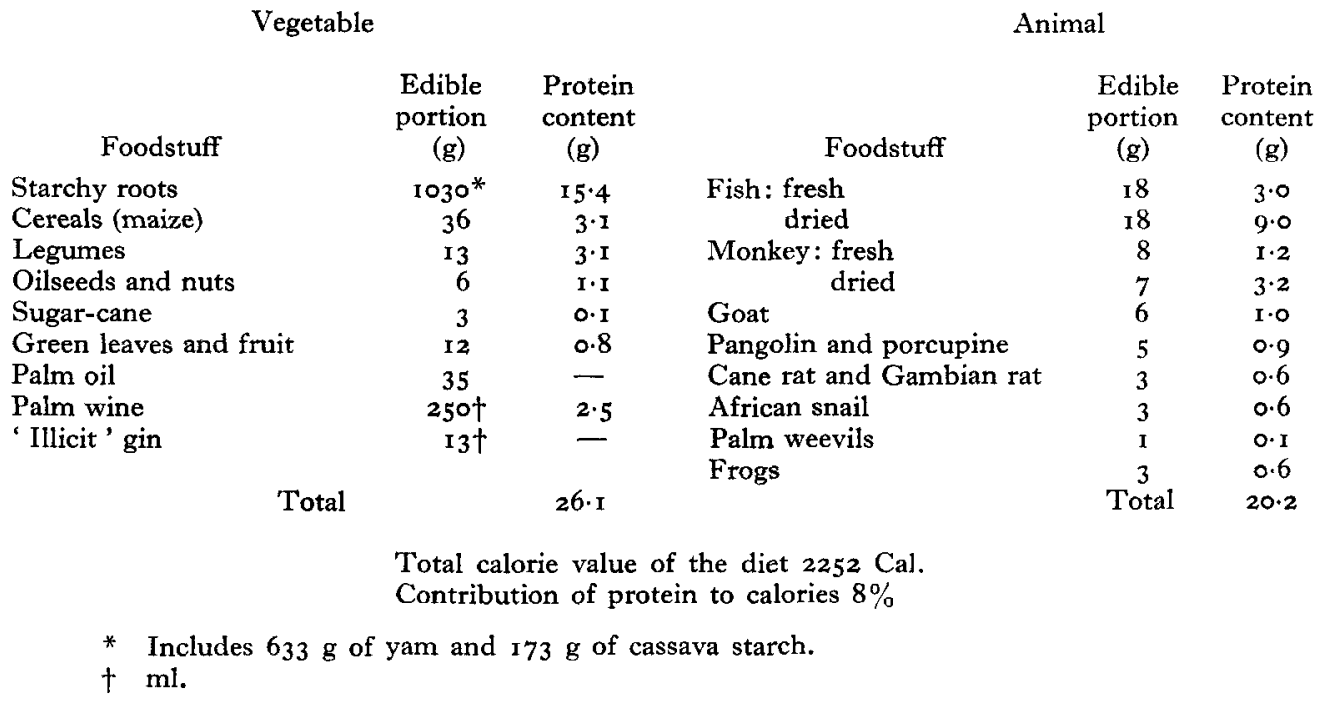

Firstly, the quantity of protein consumed by the Isoko is small, the total of $46 \mathrm{~g}$ supplying only $8 \%$ of the $2250 \mathrm{Cal}$. provided by the diet. This contrasts with the protein intake of farmers in other parts of Nigeria, e.g. in the northern provinces, who consume in the region of $75 \mathrm{~g}$ of cereal protein, this amount contributing $12 \%$ to the calorific value of the diet. Secondly, almost half the protein intake of the Isoko is derived from animal sources. Again this contrasts with the dietary pattern of farmers elsewhere in Nigeria, whose intake of animal protein is only 4 or $5 \mathrm{~g}$ daily. The third point well illustrated by the figures in Table $\mathrm{I}$ is the very low protein content of the starchy roots, $1000 \mathrm{~g}$ of yam and cassava after preparation for cooking yielding only $15 \mathrm{~g}$, whereas $72 \mathrm{~g}$ of animal foods supply $20 \mathrm{~g}$ of protein to the diet.

Fish, both fresh and dried, provides three-fifths of the animal protein in the Isoko diet, the remainder being derived from items consumed either in very small amounts or in reasonably large quantities on special occasions but these may be few and far between, as for instance when a goat is killed or a monkey shot. Thus unless careful records are kept over a long period of time it is easy to underestimate the quantity of food consumed. 
Sources of animal protein in the Isoko diet.

The foregoing general description of the Isoko possibly paints an unhappy picture of an undernourished tribe, infested with malaria and hookworms, harried by their neighbours and hunted by the denizens of the jungle. However, thanks to the ingenuity of all sections of the community, they contrive to obtain the animal foods that provide the $20 \mathrm{~g} /$ day of protein without which they would be hard pressed to exist at all. In fact the Isoko are a cheerful and contented people, fond of hunting, fishing and shooting, and it is the pursuit of these sports and the consumption of the 'bags' brought home at the end of the day that supplement the produce of their fields and adjust the amino-acid balance and vitamin content of their diet to an extent compatible with continued life and reproduction.

In view of the importance of animal protein in this diet, the methods employed for procuring it and the animals hunted will be considered briefly in the remainder of this paper. Fishing is the most important and most popular Isoko pastime. The fish most frequently caught belong to the families Cichlidae and Clariidae. The tactics employed to transfer the fish from the creek to the cooking pot are many. Various forms of traps are set, night lines are laid and yam or cassava starch soaked in palm oil is used liberally as ground bait. Vegetable fish-poisons, in particular Tephrosia vogelli, are cultivated and provide big catches. On occasions crocodiles are recruited as assistant fishermen in an ingenious way. Brushwood and stakes are arranged in a suitable part of a stream to form a thicket in the water, into which the fish retreat to escape from the crocodiles. At a set time the thicket is surrounded by a pallisade fence, and the fish are then removed from within the enclosure so formed at the convenience of the fishermen, the assistants having been previously frightened off by much noise and splashing.

Monkeys are the largest animals hunted. This is the task of the men who happen to own shot-guns. These weapons are mostly very old muzzle-loaders, and many a hand or face has been treated in the local dispensary for injuries resulting from burst barrels caused by too tight packing of the charge and shot.

The pangolin (Manis longicaudata and $M$. tricuspis) and the porcupine (Atherurus africanus) are caught in snares very similar to those used for catching rabbits in Britain. This task is carried out by the younger boys, who early in life acquire a good knowledge of the habits of these animals. Porcupine is a favoured dish among Europeans in this district, tasting best if 'jugged' as one would cook a hare in England. The giant Gambian rat (Cricetomys gambianus) and the cane rat (Thryonomys swinderianus) are shot as they break cover from the long grass in which they lie during the day. These shoots are often highly organized, the small children beating in a methodical fashion through the bush towards the stands where the guns impatiently await the opportunity to fire.

The African snail (Archachatina sp.) attains a large size, the flesh frequently weighing over $5 \circ \mathrm{g}$ after removal from the shell. Snails are collected from their habitat in thick, damp bush by the girls and women. The writer has not eaten these snails, nor the dried frogs (Rana mascarenensis) which are sold in the local markets, but 
these foods are considered a delicacy by the Isoko. Palm weevils, the larvas of Rhynchophorus phoenicis, which inhabit the boles of the red-oil palm, are eaten after roasting over an open fire. From personal experience they are very palatable to anyone who enjoys a 'palm-oil stew'.

Snakes of various species and the monitor lizard are also eaten by Isoko farmers when the opportunity arises. The whole of this tasty, if somewhat unusual, diet is washed down on high days and holidays by copious draughts of palm wine, which has been fermented for a number of days. This wine induces the stimulation, followed by sedation, that the Isoko consider essential to full enjoyment of a life pursued under anxious circumstances in an out of the way part of the world.

Nicol, B. M. (1952). Brit. F. Nutr. 6, 34 .

$$
\text { REFERENCE }
$$

\section{The Diet of Canadian Indians and Eskimos}

\section{By H. M. Sinclatr, Laboratory of Human Nutrition, University of Oxford}

Apart from racial differences, the Eskimos are unlike the Northern Indians in three respects that concern us. First, the typical Eskimos live on the coast and obtain most of their food from the sea, whereas the Indians live inland. Secondly, the Eskimos frequently eat their food raw whereas this disgusts the Indians who indeed named the Eskimos after this habit: the Cree word uskipoo means 'he eats raw meat'. Thirdly, the Eskimos live mainly north of the tree line, and although they collect some driftwood for sledges and boats they have to depend mainly upon animals, snow and rock for their houses, implements, boats, fuel and clothing; the Indians have access to wood.

\section{The foodstuffs of the Eskimos}

(cf. Amundsen, I908; Birket-Smith, 1936, I947; Egede, 1818; Eisberg \& Owens, 1949 ; Forde, I939 ; Hanson, I942 ; Karavayeva, I938 ; Rasmussen, I927 ; Stefánsson, I913, I9I4, I922, I939 b, $c$, I945, I946 ; Winn, I943 ; Yule, I948.)

Winter. Characteristic hunting is found amongst the Iglulik, Central Eskimos living north of Hudson Bay and in the north of Baffin Land, between latitudes $65^{\circ}$ to $75^{\circ} \mathrm{N}$. The long Arctic winter with a mean temperature of around $-35^{\circ} \mathrm{F}$. and short daylight hours limits activity; thick mists are usual unless dispersed by strong winds which, uninterrupted by trees, cause violent blizzards. As winter begins to set in the Eskimos congregate on the coast or floe ice. The main food throughout the winter is the seal. These animals scratch breathing-holes in the floe in the autumn and maintain them throughout the winter. The Eskimo dog scents them beneath the snow and if they are in use the hunter will fix a piece of bone in the hole which will be disturbed when the seal pushes up its nose to breathe ; then he 